\title{
IMPLEMENTASI PROGRAM JAMINAN PELAYANAN KESEHATAN MASYARAKAT BANYUWANGI (JPKMB) DALAM MEWUJUDKAN PELAYANAN KESEHATAN PRIMER BAGI SELURUH LAPISAN MASYARAKAT
}

\section{IMPLEMENTATION OF PUBLIC HEALTH SERVICES SECURITY PROGRAM BANYUWANGI (JPKMB) MAKING IN PRIMARY HEALTH CARE FOR ALL SOCIETY}

\author{
Bayu Mitra Adhyatma Kusuma \\ Universitas Islam Negeri Sunan Kalijaga, Yogyakarta \\ bayumitraa.kusuma@yahoo.com \\ Theresia Octastefani \\ Universitas Gadjah Mada, Yogyakarta \\ theresiaoctastefani@gmail.com
}

\begin{abstract}
ABSTRAK
Di era pemerintahan otonomi seperti saat ini, pemerintah daerah harus lebih kreatif dalam menciptakan terobosan untuk meningkatkan kualitas pelayanan publik. Sejumlah permasalahan masih dihadapi oleh masyarakat salah satunya pemenhan pelayanan kesehatan yang berkualitas. Pelayanan kesehatan yang dimaksud disini adalah program JPKMB di Kabupaten Banyuwangi. Penelitian ini dilakukan untuk mengetahui bagaimana pelaksanaan program JPKMB dalam mewujudkan pelayanan kesehatan bagi semua tingkat masyarakat dan bagaimana pencapaian program tersebut. Hasil penelitian ini menunjukkan bahwa pelaksanaan program JPKMB menghasilkan prestasi yang memuaskan, termasuk peningkatan jumlah kunjungan tingkat ke pusat-pusat kesehatan masyarakat, cakupan imunisasi, cakupan kunjungan ibu, bersalin ditangani oleh cakupan tenaga kesehatan, dan cakupan gizi.
\end{abstract}

\section{Kata kunci : Implementasi, Pelayanan Kesehatan Utama, Program JPKMB.}

\begin{abstract}
In the era of autonomy such as this, local governments need to be more creative in creating a breakthrough to improve the quality of public services. A number of problems still faced by the community one pemenhan quality health care. Health services in question here is JPKMB program in Banyuwangi. This study was conducted to determine how the implementation of the program JPKMB in realizing health care for all levels of society, and how the achievement of the program. The results showed that the implementation of the program JPKMB produce satisfactory progress, including an increase in the number of visits to the level of community health centers, immunization coverage, coverage visit mothers, maternity coverage is handled by health personnel, and nutritional coverage.
\end{abstract}

Keywords : Implementation, Primary Health Service, JPKMB Program 


\section{PENDAHULUAN}

Otonomi daerah telah bergulir di Indonesia seiring lahirnya UU No. 22 Tahun 1999, kemudian UU No. 32 Tahun 2004, dan kini telah disempurnakan dengan UU No. 23 Tahun 2014. Berdasarkan undang-undang tersebut dapat diambil suatu benang merah bahwa otonomi daerah mencakup dua hal pokok yaitu: pertama, pemberian kewenangan dari pemerintah pusat kepada pemerintah daerah, bukan hanya sekedar pendistribusian otoritas seperti pada UU No. 5 Tahun 1974. Kedua, pemberian tanggungjawab yang lebih besar kepada daerah. Artinya apabila suatu daerah telah diberikan kewenangan untuk mengelola potensi yang dimilikinya maka pada saat itu juga daerah mendapat tanggungjawab untuk mengawasi pengelolaan potensi tersebut.

\section{Tentu pemberian} kewenangan tersebut berimplikasi pada aparatur daerah serta lembaga pelayanan publiknya dimana mereka harus dapat mempertanggung jawabkan segala tindakan dan aktivitasnya untuk memberikan pelayanan publik yang layak kepada masyarakat. Berkaitan dengan digulirkannya otonomi daerah tersebut, pemerintah daerah sebagai abdi negara dan abdi masyarakat harus senantiasa berupaya meningkatkan kinerja aparatur daerah yang ada di dalamnya. Hal tersebut karena pemerintah tidaklah diadakan untuk melayani dirinya sendiri, melainkan untuk melayani masyarakat. Sebagaimana dijelaskan oleh Siagian (2000:134) bahwa pemerintah memiliki dua fungsi yaitu fungsi pengaturan (regulatory function) dan fungsi pelayanan (service function).

Fungsi pelayanan publik menjadi isu yang semakin strategis karena perbaikan pelayanan publik di Indonesia masih cenderung stagnan. Sedangkan implikasi dari fungsi pelayanan sangatlah luas dalam kehidupan ekonomi, politik, ataupun sosial budaya. Buruknya pelayanan publik di Indonesia sering menjadi penyebab dominan yang sangat mempengaruhi tingkat kepuasan masyarakat. Sebagaimana kita ketahui, ada berbagai pelayanan publik yang berperan vital dalam kehidupan masyarakat. Salah satu jenis pelayanan publik yang sangat vital bagi masyarakat tersebut adalah pelayanan kesehatan.

Kesehatan merupakan suatu kebutuhan dasar manusia. Keberhasilan pembangunan kesehatan sangat dipengaruhi oleh ketersediaan tenaga sumber daya manusia yang sehat, terampil dan ahli serta disusun dalam suatu program kesehatan dengan perencanaan terpadu yang didukung oleh data dan informasi epidemiologi yang valid. (Depkes RI, 2005). 
Di level kota atau kabupaten, pelayanan kesehatan dilaksanakan oleh rumah sakit umum daerah dengan Pusat Kesehatan Masyarakat (Puskesmas) sebagai ujung tombaknya, sehingga Puskesmas harus meyelenggarakan pelayanan kesehatan secara maksimal. Pelayanan kesehatan yang diberikan pada masyarakat miskin pun harus diperhatikan karena seringkali dibedakan.

Memang tidak dapat dipungkiri bahwa pelayanan kesehatan masyarakat miskin seringkali menjadi permasalahan terutama dalam hal biaya. Hal tersebut memacu pemerintah daerah untuk memunculkan terobosan dan kebijakan di bidang kesehatan. Munculnya program Jaminan Pelayanan Kesehatan Masyarakat Banyuwangi (JPKMB) merupakan jawaban dan upaya dalam menyetarakan pelayanan kesehatan primer antara masyarakat miskin dengan masyarakat mampu sehingga pelayanan kesehatan primer di Kabupaten Banyuwangi dapat dirasakan oleh seluruh lapisan masyarakat.

Dengan demikian maka seluruh lapisan masyarakat di Kabupaten Banyuwangi mendapatkan pelayanan kesehatan primer di Puskesmas se-Kabupaten Banyuwangi secara gratis. Dari hal tersebut dapat diambil suatu benang merah bahwa pemberian pelayanan kesehatan primer kepada seluruh lapisan masyarakat harus diberikan secara adil dan merata tanpa memandang latar belakang status perekonomian.

Pemerintah
Kanyupaten
meningkatkan pelayanan kesehatan
untuk masyarakat melalui adanya
program JPKMB. Namun perlu
digarisbawahi bahwa sebaik-baiknya
suatu program ataupun kebijakan
akan gagal bila di tataran
pelaksanaanya tidak dilakukan
dengan baik dan benar. Hal ini
ditunjukkan dalam realita yang ada
bahwa saat ini angka kesakitan
(morbidity) di wilayah Kabupaten
Banyuwangi masih cukup tinggi.
Angka kesakitan berhubungan
dengan terjadinya penyakit di dalam
populasi, baik fatal maupun non
fatal.

Untuk menganalisis secara mendalam permasalahan tersebut, penulis berlandaskan dengan perspektif New Public Service (NPS) dari Denhardt dan Denhardt (2003:73-74). Secara ringkas, perspektif NPS dapat dilihat dari beberapa prinsip, antara lain: serve citizens not customers; seek public interest; value citizenship over enterpreneurship; think strategicaly act democratically; recognize that accountability not simple; serve rather than steer; dan value people, not just productivity. 
Dengan diadopsinya tujuh poin dalam prinsip-prinsip NPS secara konsekuen, pelayanan kesehatan primer melalui program JPKMB diharapkan semakin membumi. Berdasarkan pemaparan diatas, maka penulis tertarik untuk mengkajinya lebih dalam, sehingga penulis tertarik untuk mengkaji implementasi program JPKMB dan pencapaiannya dalam mewujudkan pelayanan kesehatan primer bagi seluruh lapisan masyarakat di Kabupaten Banyuwangi. Selain itu ingin melihat sejauhmana program JPKMB ditinjau dari perspektif New Public Service.

\section{KAJIAN TEORITIS}

\section{Implementasi Kebijakan}

Kebijakan atau policy menurut Friedrich (Wahab, 2005:3) ialah suatu tindakan yang mengarah pada tujuan yang disusulkan oleh seseorang, kelompok, atau pemerintah dalam lingkungan tertentu sehubungan dengan adanya hambatan-hambatan tertentu seraya mencari peluang-peluang untuk mencapai tujuan atau mewujudkan sasaran yang diinginkan. Selanjutnya Dunn (2006:65) mengemukakan bahwa kebijakan publik atau public policy adalah rangkaian panjang pilihan-pilihan yang kurang lebih berhubungan, termasuk keputusan untuk tidak berbuat, yang dibuat oleh kantor-kantor atau badan-badan pemerintah.
Implementasi merupakan aspek yang penting dari keseluruhan proses kebijakan. Implementasi kebijakan adalah sesuatu yang sangat penting, karena kebijakan-kebijakan akan sekedar berupa impian atau rencana bagus yang tersimpan rapi dalam arsip jika tidak benar-benar diimplementasikan.

\section{Istilah policy implementation} adalah pelaksanaan dan pengarahan tindakan kebijaksanaan dalam jangka waktu tertentu Dunn (2003:64). Sedangkan menurut Parsons (2006:463), studi impelementasi adalah studi perubahan: bagaimana perubahan terjadi, bagaimana kemungkinan perubahan bisa dimunculkan. Ia juga merupakan studi tentang mikrostruktur dari kehidupan politik; bagaimana organisasi di luar dan di dalam sistem politik menjalankan urusan mereka dan berinteraksi satu sama lain; apa motivasi-motivasi mereka bertindak seperti itu, dan apa motivasi lain yang mungkin membuat mereka bertindak secara berbeda. Salah satu bentuk dari implementasi kebijakan adalah dengan melalui pelayanan publik, misalnya pelayanan kesehatan.

\section{Pelayanan Kesehatan Primer}

Menurut Sinambela

(Pasolong, 2008:128) pelayanan publik adalah setiap kegiatan yang dilakukan oleh pemerintah terhadap sejumlah manusia yang memiliki 
setiap kegiatan yang menguntungkan dalam suatu kumpulan atau kesatuan dan menawarkan kepuasan meskipun hasilnya tidak terkait pada suatu produk secara fisik. Atau dapat dikatakan bahwa pelayanan publik adalah kegiatan atau aktivitas yang dilakukan pemerintah sebagai penyedia pelayanan kepada publik dalam rangka pemenuhan kebutuhan baik berupa barang maupun jasa.

Dalam perkembangannya, setidaknya ada tiga perspektif pelayanan publik yang berkembang dari masa kemasa. Ketiga perspektif tersebut adalah: Administrasi Publik Lama (Old Public Administration/OPA), Manajemen Publik Baru (New Public Management/NPM), dan Pelayanan Publik Baru (New Public Service/NPS). Menurut Denhardt dan Denhardt (Dwiyanto, 2008:138), apabila ketiga perspektif tersebut dibandingkan dalam sebuah tabel adalah sebagai berikut :
Tabel 1.

Pergeseran Paradigma Model

Pelayanan Publik

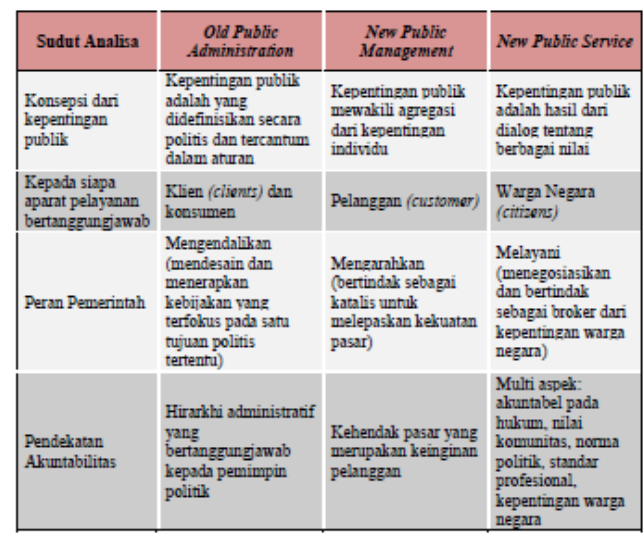

Sumber : Denhardt dan Denhardt (Dwiyanto, 2008:139)

Sebagaimana telah dijelaskan sebelumnya bahwa salah satu jenis pelayanan publik yang sangat vital adalah pelayanan kesehatan, terutama pelayanan kesehatan primer. Pelayanan kesehatan adalah suatu bentuk upaya dalam peningkatan derajat kesehatan. Menurut Pohan (2007:5), pelayanan kesehatan yang bermutu adalah pelayanan kesehatan yang selalu berupaya memenuhi harapan pasien sehingga akan selalu merasa berhutang budi serta sangat berterima kasih.

Pelayanan kesehatan, terutama pelayanan kesehatan dasar atau primer adalah salah satu bentuk pelayanan publik yang sangat diperhatikan oleh pemerintah, hal ini dibuktikan dengan sebagaimana tercantum dalam UU No. 36 Tahun 
2009 Pasal 1 yaitu setiap kegiatan atau serangkaian kegiatan yang dilakukan secara terpadu, terintregasi, dan berkesinambungan untuk memelihara dan meningkatkan derajat kesehatan masyarakat dalam bentuk pencegahan penyakit, peningkatan kesehatan, pengobatan penyakit, dan pemulihan kesehatan oleh pemerintah dan masyarakat. Berkaitan dengan hal tersebut, di Kabupaten Banyuwangi pemenuhan pelayanan kesehatan primer diwujudkan melalui program JPKMB.

\section{Program JPKMB}

Berdasarkan Peraturan Bupati Banyuwangi No. 13 Tahun 2011 tentang Pedoman Pelaksanaan Program Jaminan Pelayanan Kesehatan Masyarakat Banyuwangi, program Jaminan Pelayanan Kesehatan Masyarakat Banyuwangi (JPKMB) adalah program yang dicanangkan Pemerintah Kabupaten Banyuwangi untuk memenuhi hak primer warga masyarakat Banyuwangi di bidang perlindungan dan pemeliharaan kesehatan guna peningkatan derajat kesehatan yang layak dengan mengalihkan beban biaya pembayaran retribusi pelayanan kesehatan, rawat jalan tingkat primer di Puskesmas dan jaringannya yang ditanggung oleh masyarakat menjadi beban Pemerintah Kabupaten Banyuwangi.
Program JPKMB ditujukan kepada warga masyarakat di Kabupaten Banyuwangi yang memiliki kartu JPKMB, Kartu Tanda Penduduk (KTP) Kabupaten Banyuwangi atau identitas lainnya yang mampu menunjukkan sebagai warga masyarakat Kabupaten Banyuwangi. Adapun pengelola program JPKMB adalah Tim pelaksana Program JPKMB yang struktur organisasinya berada di bawah naungan Dinas Kesehatan Kabupaten Banyuwangi dan pembentukannya ditetapkan melalui keputusan Bupati Banyuwangi.

Tujuan pelaksanaan program JPKMB adalah untuk memberikan keringanan atau bebas biaya pengobatan pelayanan kesehatan, rawat jalan tingkat primer di Puskesmas kepada masyarakat di Kabupaten Banyuwangi dan menekan sekecil mungkin pelayanan kesehatan rujukan di rumah sakit. Program JPKMB dilaksanakan dengan mengedepankan prinsip kejujuran, transparan, dan akuntabel.

\section{METODE PENELITIAN}

Dalam penelitian ini jenis penelitian yang digunakan adalah kualitatif dengan pendekatan deskriptif. Denzin dan Lincoln (Moleong, 2009:5) menyebutkan bahwa penelitian kualitatif adalah penelitian yang menggunakan latar alamiah yang bermaksud untuk menafsirkan fenomena yang terjadi 
dan dilakukan dengan jalan melibatkan berbagai metode yang ada. Untuk memperoleh data-data yang diperlukan dalam penelitian ini, teknik penelitian yang digunakan di bedakan menjadi tiga, yaitu observasi, wawancara, dan penelusuran dokumen terkait. Dalam penelitian ini teknik analisis data yang digunakan adalah model Spradley. Analisis data model ini memanfaatkan adanya hubungan semantik. Sebagaimana gambar berikut :

\section{Gambar 1.}

\section{Proses Analisis Data Model Spradley}

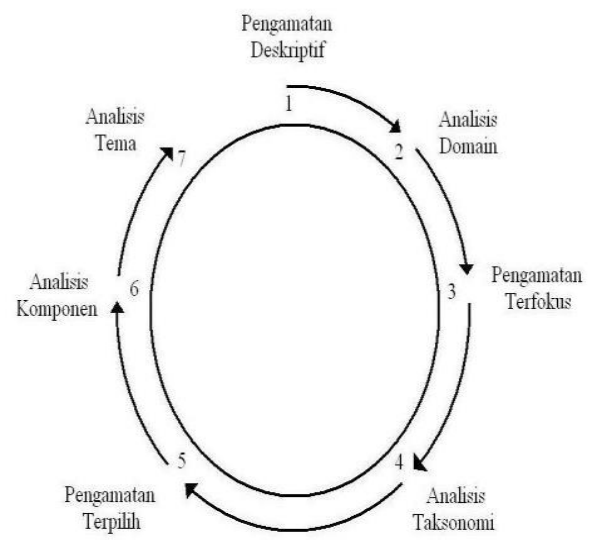

Sumber : Spradley (Sugiyono, 2009: 244)

Secara operasional, analisis data model Spradley dilakukan melalui empat tahap yang apabila dijabarkan adalah sebagai berikut:

1. Analisis domain (domain analysis). Dilakukan saat peneliti memasuki objek penelitian dan melakukan pengamatan deskriptif melalui observasi, wawancara, dan dokumentasi;

2. Analisis taksonomi (taxonomic analysis). Dilakukan dengan menentukan domain-domain tertentu yang dijadikan fokus penelitian;

3. Analisis komponensial (componential analysis). Dilakukan dengan cara observasi dan wawancara terseleksi untuk mencari ciri spesifik pada setiap struktur di suatu bidang;

4. Analisis tema kultural (cultural theme analysis). Dilakukan dengan cara mencari hubungan di antara domain dan bagaimana hubungan dengan keseluruhan yang selanjutnya dinyatakan dalam sebuah tema/judul penelitian.

\section{PEMBAHASAN}

\section{Implementasi Program JPKMB}

$$
\text { Pelayanan kesehatan }
$$
merupakan kebutuhan masyarakat yang sangat penting dan perlu mendapatkan perhatian yang besar dari aparat pemerintah, dalam hal ini Dinas Kesehatan beserta Puskesmas dan jaringannya, karena hal ini 
menyangkut kepentingan umum masyarakat secara keseluruhan.

\section{Pemerintah sebagai} penyelenggara pelayanan publik harus dapat menjamin hak masyarakat luas untuk hidup sehat dengan memberikan pelayanan kesehatan secara merata, adil, memadai, terjangkau, dan berkualitas. Dalam realitasnya, sejak tahun 1997 Pemerintah memang telah mulai memberikan pelayanan gratis bagi masyarakat miskin, terutama sejak berlakunya program JPKMB, bagi masyarakat di luar miskin dan askes wajib untuk tetap diberikan pelayanan kesehatan yang berkualitas dan memadai. Sehingga pelayanan kesehatan melalui program JPKMB ditujukan untuk memberikan pelayanan kesehatan primer kepada seluruh lapisan masyarakat tanpa memandang kaya miskin, derajat ekonomi, atau status sosial masyarakat.

Secara normatif, pelayanan kesehatan haruslah mencakup pelayanan yang sifatnya primer maupun sekunder yang dilakukan secara secara menyeluruh, terpadu dan berkesinambungan mencakup pelayanan kesehatan perorangan maupun pelayanan kesehatan masyarakat. Adapun dalam realitasnya, untuk pelayan kesehatan yang sifatnya sekunder dikenakan biaya. Pelayanan Kesehatan yang tidak dijamin atau harus membayar sesuai dengan ketentuan yang berlaku, meliputi: pemeriksaan kesehatan untuk Surat Keterangan Sehat yang bukan calon tenaga kerja dan pelajar, pemeriksaan calon pengantin, pemeriksaan haji, pemeriksaan yang spesialistik, pemeriksaan laboratorium sedang dan rontgen, pelayanan kosmetika, pengobatan alternatif, rotesis (gigi tiruan dan korset), alat dan obat kontrasepsi selain peruntukan bagi keluarga miskin, circumsisi dan tindik, pertolongan persalinan anak ke-3 dan seterusnya, rawat inap di Puskesmas, rawat jalan tingkat lanjutan dan rawat inap di Rumah Sakit dan tempat-tempat pelayanan lain selain Puskesmas, dan pelayanan yang tidak sesuai prosedur dan ketentuan.

Adapun pelayanan yang dijamin oleh program JPKMB adalah pelayanan kesehatan primer, sehingga tidak dikenai biaya sama sekali atau gratis. Pelayanan kesehatan yang dijamin di dalam program JPKMB atau tidak dikenai biaya tersebut meliputi: Rawat jalan tingkat pertama (konseling/ konsultasi kesehatan, pemeriksaan umum, pemberian obat-obatan sesuai ketentuan, pemeriksaan dan pengobatan gigi, laboratorium sederhana, tindakan medis sederhana, pemeriksaan kesehatan ibu dan anak, pemberian imunisasi, pelayanan dan pengobatan gawat darurat, pemeriksaan kesehatan calon tenaga kerja dan pelajar, dan penyuluhan gizi), pertolongan 
persalinan normal di Puskesmas (persalinan anak pertama dan kedua di Puskesmas, penanganan persalinan normal di Puskesmas dalam rentang pelayanan pertolongan persalinan mengalami penyulit/ komplikasi dan harus dilakukan upaya rujukan ke Puskesmas pelayanan obstetri neonatal emergency dasar atau rumah sakit pelayanan obstetri neonatal emergency komprehensif, penanganan/ pencegahan komplikasi paska keguguran di dalam gedung Puskesmas), dan pelayanan kesehatan di luar gedung Puskesmas di dalam wilayah kerja Puskesmas (Pelayanan rawat jalan dengan Puskesmas keliling, balai pengobatan, Polindes, dan Posyandu, pelayanan penanggulangan penderita gawat darurat pada kegiatan tertentu yang diperlukan, pelayanan kesehatan melalui kunjungan rumah, penyuluhan kesehatan di masyarakat, pemberian Imunisasi, pemeriksaan ibu hamil/ nifas/ menyusui dan balita.

Dengan demikian dapat dipahami dan diketahui bahwa dalam realitas di lapangan, peneliti mendapatkan bahwa ada dua jenis pelayanan kesehatan yang dilayanai, yaitu pelayanan kesehatan yang bersifat sekunder atau tidak dijamin dalam program JPKMB dan pelayanan kesehatan yang bersifat primer atau dijamin dalam program JPKMB sehingga dalam pelayanannya tidak dekenakan biaya sama sekali atau gratis.

Setiap kegiatan yang sifatnya formal pasti memiliki prosedur. Prosedur dibuat dengan tujuan agar suatu program dapat dijalankan secara sistematis dan teratur. Prosedur pelayanan kesehatan adalah tata cara masyarakat untuk memperoleh pelayanan kesehatan yang dibutuhkan. Program JPKMB juga memiliki prosedur tertentu agar dilaksanakan secara sistematis dan teratur. Di bawah ini merupakan prosedur pelayanan kesehatan primer yang diberikan melalui program JPKMB di Puskesmas dan jaringannya, yaitu: masyarakat yang memerlukan pelayanan kesehatan primer datang ke Puskesmas dan jaringannya, Puskesmas dan jaringannya memberikan pelayanan kesehatan primer sesuai kebutuhan dan standar pelayanan, masyarakat yang berkunjung ke Puskesmas harus dapat menunjukkan kartu identitas diri berupa Kartu JPKMB atau KTP, dan dalam kondisi gawat darurat masyarakat dapat langsung ke Puskesmas melalui unit gawat darurat. Masyarakat yang tidak mematuhi aturan/prosedur di atas tidak tertanggung dalam program JPKMB.

Program JPKMB sama sekali tidak memungut biaya dari masyarakat karena sebagai gantinya puskesmas dapat mengajukan klaim kepada Dinas Kesehatan untuk 
diverifikasi kebenaran dari klaim tersebut dan kemudian dana akan dikucurkan secara wajar dan profesional. Secara detail pengajuan penggantian biaya dapat dilakukan oleh Puskesmas dengan memperhatikan tempat pelayanan, koefisien besaran pengganti, tata cara dan syarat penggantian biaya. Biaya pengganti yang diterima Puskesmas tidaklah sama setiap bulannya. Besarnya biaya pengganti yang diterima didasarkan pada klaim yang diajukan Puskesmas kepada Dinas Kesehatan Kabupaten Banyuwangi dan kemudian dilanjutkan dengan verifikasi atas klaim tersebut.

\section{Pencapaian Program JPKMB}

Implementasi dari program
JPKMB terus menunjukkan
perkembangan 4 yang cukup
menggembirakan dari tahun ke
tahun. Terdapat peningkatan di
semua sektor. Di bawah ini
merupakan perbandingan antara tahun 2005, 2009, dan 2012 dalam persen (\%). Pertama, angka kunjungan atau juga disebut angka utilisasi atau visite rate adalah tingkat pemanfaatan pelayanan kesehatan primer yang ditinjau dari jumlah kunjungan pasien di puskesmas dibandingkan dengan seluruh penduduk Banyuwangi. Perbandingan visite rate tersebut adalah sebagai berikut :
Gambar 4.

Visite Rate Program JPKMB

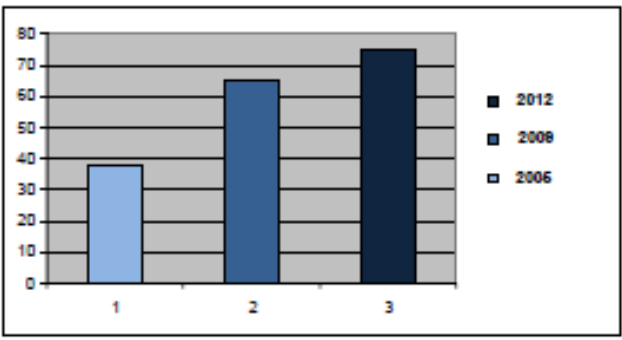

Sumber: Laporan Tahunan Program JPKMB 2012

Berdasarkan data pada grafik di atas dapat dilihat bahwa bahwa terdapat peningkatan cakupan jumlah kunjungan. Jumlah penduduk Kabupaten Banyuwangi adalah 1.540.000 jiwa, sebelum adanya Program JPKMB pada tahun 2005 jumlah kunjungan adalah $39 \%$ atau berarti 602.602 jiwa telah menggunakan pelayanan kesehatan primer sebelum adanya program JPKMB. Kemudian meningkat sesudah adanya Program JPKMB pada tahun 2009 menjadi $70 \%$ atau 1.073.000 jiwa telah memanfaatkan layanan JPKMB) dan pada tahun 2012 menjadi $76 \%$ sehingga sampai tahun 2012 sejumlah 1.185.272 jiwa telah memanfaatkan layanan program JPKMB. Kedua, angka cakupan kelengkapan imunisasi. Terlihat pada indikator rata-rata bayi terimunisasi lengkap. Perbandingan cakupan pelayanan imunisasi adalah sebagai berikut: 
Gambar 5.

Cakupan Pelayanan Imunisasi

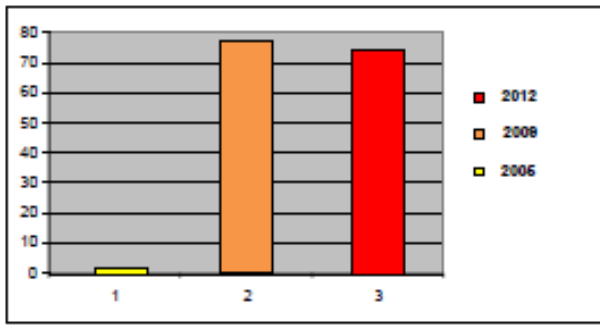

Sumber: Laporan Tahunan Program JPKMB 2012

Berdasarkan data pada grafik di atas maka dapat diketahui bahwa terdapat peningkatan yang cukup besar antara cakupan pelayanan imunisasi sebelum adanya Program JPKMB tahun 2005 hanya 20\%, setelah adanya Program JPKMB tahun 2009 sebanyak 77\% (meningkat 57\%) dan tahun 2012 sebanyak $77 \%$ (satgnan namun mengalami penurunan dalam hitungan desimal). Ketiga, pencapaian cakupan kunjungan ibu hamil (maternal). Secara keseluruhan di Kabupaten Banyuwangi dari tahun ke tahun terus menunjukkan peningkatan. Secara detail pencapaian cakupan kunjungan ibu hamil adalah sebagai berikut :
Gambar 6. Cakupan Kunjungan Maternal

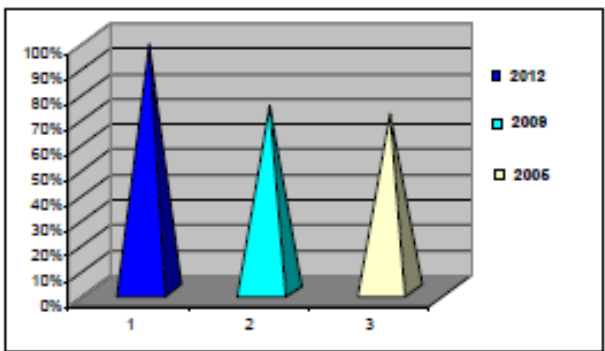

Sumber: Laporan Tahunan Program JPKMB 2012

Berdasarkan data pada grafik di atas maka diketahui terdapat peningkatan antara cakupan kunjungan ibu hamil sebelum adanya program JPKMB tahun 2005 sejumlah 65\% setelah adanya Program JPKMB tahun 2009 sejumlah $78 \%$ (meningkat $7 \%$ ) dan tahun 2012 sejumlah $93 \%$ (meningkat 14\%).

Meningkatnya kunjungan ibu hamil tersebut kemudian juga mempengaruhi jumlah cakupan persalinan yang ditangani oleh tenaga kesehatan. Cakupan persalinan yang ditangani oleh tenaga kesehatan di Kabupaten Banyuwangi dijelaskan pada gambar di bawah ini: 
Gambar 7.

Cakupan Persalinan oleh Tenaga

Kesehatan

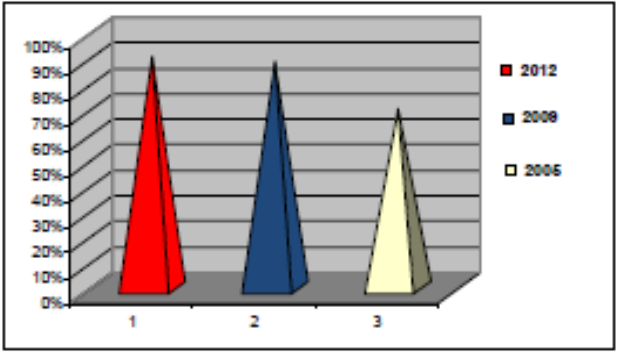

Sumber: Laporan Tahunan Program JPKMB 2012

Berdasarkan data pada grafik di atas maka diketahui terdapat peningkatan antara Cakupan kelahiran ibu hamil yang ditangani oleh petugas kesehatan sebelum adanya program JPKMB tahun 2005 sejumlah $86 \%$ setelah adanya program JPKMB tahun 2009 sejumlah $92 \%$ (meningkat 6\%) dan tahun 2012 sejumlah $93 \%$ (meningkat $1 \%$ ).

Dan terakhir adalah cakupan gizi. Cakupan gizi diketahui melalui jumlah kunjungan balita ke posyandu dibandingkan seluruh balita yang ada, menggambarkan tingkat partisipasi masyarakat terhadap kegiatan posyandu dan kesehatan balitanya, yang dijelaskan pada gambar berikut ini.
Gambar 8 .

Cakupan Gizi Balita

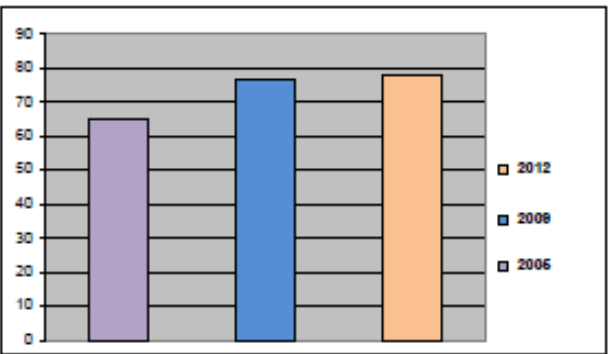

Sumber: Laporan Tahunan Program JPKMB 2012

Berdasarkan data pada grafik di atas maka diketahui terdapat peningkatan antara cakupan gizi balita sebelum adanya Program JPKMB tahun 2005 sejumlah $73 \%$ setelah adanya Program JPKMB tahun 2009 sejumlah $78 \%$ (meningkat 5\%) dan tahun 2012 sejumlah $79 \%$ (meningkat $1 \%$ ).

Berpijak pada data grafik di atas, dapat disimpulkan bahwa implementasi program JPKMB terus mengalami peningkatan dari tahun ke tahun. Hal tersebut membuktikan bahwa dapat dikatakan program JPKMB ini adalah program yang sukses. 
Program JPKMB dalam Perspektif New Public Service

Di bawah ini adalah uraian analisis implementasi program JPKMB bila ditinjau dari perpektif NPS:

1. Melayani warga negara, bukan pelanggan.

Program JPKMB tidak memberikan pelayanan kesehatan semata-mata untuk mencari keuntungan atau melayani masyarakat sebagai customer, melainkan melayani masyarakat sebagai citizen. Ini dibuktikan dengan program JPKMB sama sekali tidak menarik biaya dari masyarakat dan memberikan pelayanan kesehatan primer kepada seluruh lapisan masyarakat.

2. Mengutamakan kepentingan publik.

Pemerintah Kabupaten Banyuwangi, Dinas Kesehatan, dan Puskesmas sebagai pelaksana program JPKMB berkontribusi untuk memenuhi kebutuhan publik akan pelayanan kesehatan primer berkualitas dan terjangkau.

3. Menghargai warga negara daripada kewirausahaan.

Kepentingan publik akan lebih baik jika dijalankan oleh pejabat publik. Misalnya pelayanan kesehatan lebih baik dijalankan oleh instansi pemerintah dijalankan oleh pihak swasta yang pasti akan menarik biaya dengan mahal. Hal inilah yang menjadi model penerapan dari program JPKMB dimana program JPKMB diselenggarakan oleh Pemerintah Kabupaten Banyuwangi melalui Dinas Kesehatan dengan Puskesmas dan jaringannya sebagai ujung tombaknya.

4. Berpikir stategis dan bertindak secara demokratis.

Program

JPKMB merupakan suatu strategi dari Pemerintah Kabupaten Banyuwangi dalam upaya meningkatkan derajat kesehatan masyarakat di Kabupaten Banyuwangi. Program JPKMB dapat berjalan secara efektif dan lebih bertanggungjawab apabila ada kolaborasi antara Pemerintah Kabupaten Banyuwangi, Puskesmas, dan masyarakat sebagai pengguna layanan.

5. Mengakui bahwa akuntabilitas bukanlah hal yang sederhana.

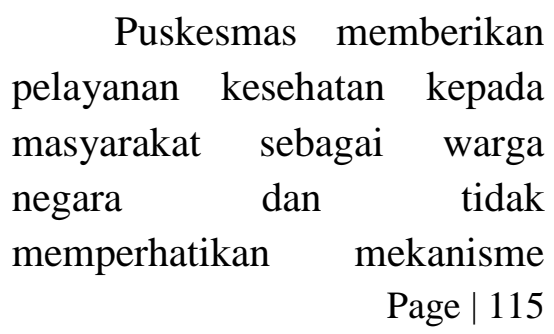


pasar yang selalu bermain dengan permintaan dan penawaran dalam menentukan harga. Selain itu, pelaksana program JPKMB yaitu Puskesmas juga harus mematuhi peraturan perundang-undangan, nilainilai kemasyarakatan, standar profesional, dan kepentingan warga negara dalam memberikan pelayanan kesehatan.

6. Mengutamakan pelayanan daripada mengatur.

Pemerintah Kabupaten Banyuwangi, Dinas Kesehatan Kabupaten Banyuwangi, dan Puskesmas menggunakan kepemimpinan dan kewenangan yang berbasis pada nilai bersama dalam membantu warga masyarakat untuk memenuhi kebutuhan akan pelayanan publik daripada mengontrol sehingga mereka mengetahui apa yang sebenarnya dibutuhkan oleh masyarakat.

7. Menghargai orang lain, bukan dari produktifitas.

Puskesmas dalam memberikan pelayanan kesehatan primer kepada publik dilandasi dengan sikap menghargai masyarakat selaku pasien atau pengguna layanan. Selain itu Puskesmas dalam melaksanakan program JPKMB tidak bekerja untuk mencari pemasukan. Dengan menghargai masyarakat, maka masyarakat juga akan menjadi semakin puas terhadap pelayanan kesehatan melalui program JPKMB.

Berdasarkan uraian di
atas, maka $r$ penulis
menyimpulkan
implementasi program JPKMB
telah menerapkan prinsip-
prinsip New Public Service.

\section{KESIMPULAN}

Pelayanan

kesehatan merupakan bagian dari pelayanan publik yang oleh Pemerintah Kabupaten Banyuwangi diwujudkan dalam program Jaminan Pelayanan Kesehatan Masyarakat Banyuwangi (JPKMB). Program JPKMB adalah suatu program yang diadakan Pemerintah Kabupaten Banyuwangi untuk mewujudkan pelayanan kesehatan primer bagi seluruh lapisan masyarakat.

Dalam pelaksanaanya ujung tombak dari pelaksanaan program Puskesmas dan jaringannya. Program JPKMB dilakukan tanpa dipungut biaya karena telah didanai oleh pemerintah Kabupaten Banyuwangi melalui APBD yang dikucurkan kepada Puskesmas sebagai biaya pengganti. Adanya program JPKMB memberikan dampak positif yang ditunjukkan dengan berbagai Page | 116 
pencapaian. Pencapaian ditandai dengan meningkatnya angka kunjungan, cakupan imunisasi, cakupan kunjungan ibu hamil, cakupan persalinan yang ditangani tenaga kesehatan, dan cakupan jumlah kunjungan posyandu. Pelayanan program JPKMB telah menggunakan prinsip-prinsip New Pubilc Service yang dibuktikan dengan dipenuhinya tujuh poin yang ada dalam NPS. Sehingga disini masyarakat dilayani bukan sebagai customer melainkan sebagai citizen.

\section{SARAN}

Perlu adanya partisipasi yang lebih aktif dari masyarakat selaku pengguna layanan program JPKMB untuk memanfaatkan program ini secara maksimal. Peran masyarakat dapat membantu kinerja puskesmas dan meningkatkan derajat kesehatan masyarakat. Pemerintah Kabupaten Banyuwangi diharapkan semakin mempermudah alur pencairan biaya pengganti JPKMB agar kinerja dan kegiatan operasional puskesmas seperti misalnya Puskesmas tidak terhambat.

\section{DAFTAR PUSTAKA}

Denhardt, Janet V. dan Denhardt, Robert B. 2003. The New Public Service: Serving, not Steering. London: M.E. Sharpe.

Departemen Kesehatan
Pembangunan 2005. Jakarta: Pusdatin-Depkes RI.
Dunn, William N. 2003. Pengantar Analisis Kebijakan Publik. Yogyakarta: Gadjah Mada University Press.

Dwiyanto, Agus. 2008. Mewujudkan Good Governance Melalui Pelayanan Publik. Yogyakarta: Gadjah Mada University Press.

Kabupaten Banyuwangi. 2011. Peraturan Bupati Banyuwangi No. 13 Tahun 2011 tentang Pedoman Pelaksanaan Program Jaminan Pelayanan Kesehatan Masyarakat Banyuwangi.

Kabupaten Banyuwangi. 2012. Laporan Tahunan Program JPKMB Tahun 2012.

Moleong, Lexy J. 2009. Metode Penelitian Kualiatif. Bandung: Remaja Rosdakarya.

Parson, Wayne. 2006. Public Policy: Pengantar Teori dan Praktik Analisis Kebijakan. Jakarta: Kencana Prenada Media.

Pohan, Imbalo. 2007. Jaminan Mutu Layanan Kesehatan: DasarDasar Pengertian dan Penerapan. Jakarta: Buku Kedokteran EGC.

Republik Indonesia. UU No. 5 Tahun 1974 tentang Pokok-Pokok pemerintahan di Daerah. 
Republik Indonesia. UU No. 22 Tahun 1999 tentang Pemerintahan Daerah.

Republik Indonesia. UU No. 32 Tahun $2004 \quad$ tentang Pemerintahan Daerah.

Republik Indonesia. UU No. 23 Tahun $2014 \quad$ tentang Pemerintahan Daerah.

Siagian, Sondang P. 2000. Administrasi Pembangunan. Jakarta: Bumi Aksara.
Sugiyono. 2009. Metode Penelitian Kuantitatif, Kualitatif, dan $R \& D$. Bandung: Alfabeta.

Wahab, Solichin A. 2005. Analisis Kebijaksanaan: Dari Formulasi ke Implementasi Kebijaksanaan. Jakarta: Bumi Aksara. 